\title{
Van vaccinateur tot academisch opgeleid arts. Over de geschiedenis van het medisch onderwijs in Nederlands-Indië
}

\author{
R.P. Zwierstra
}

\section{Samenvatting}

In de tweede helft van de negentiende eeuw werd in het voormalig Nederlands-Indië een begin gemaakt met medisch onderwijs. Aanvankelijk werden inlanders in twee jaar opgeleid tot vaccinateur, later tot inlands arts met een uitgebreider curriculum. In Batavia werd daartoe de School Tot Opleiding van Inlandsche Artsen (STOVIA) opgericht en veel later in Soerabaya de Nederlandsch Indische Artsen School (NIAS). Veranderingen in de opvattingen over kolonialisme en het cultuurstelsel hebben hierbij een doorslaggevende rol gespeeld.

In het begin van de twintigste eeuw werd de opleiding op universitair niveau gebracht en werden fundamentele curriculumveranderingen ingevoerd. In die context werd ook ruimte geboden voor de ontwikkeling van ideeën over onafhankelijkheid en zelfbestuur, waarmee de basis werd gelegd voor een groot aandeel van artsen en medische studenten in de onafhankelijkheidsbeweging. Na de Tweede Wereldoorlog nam het aantal medische faculteiten in Indonesië geleidelijk toe. Na een korte onderbreking, veroorzaakt door de Nieuw-Guinea crisis, is de samenwerking met Nederland op onderwijsgebied weer hersteld. (Zwierstra RP. Van vaccinateur tot academisch opgeleid arts. Over de geschiedenis van het medisch onderwijs in NederlandsIndië. Tijdschrift voor Medisch Onderwijs 2009;28(2):81-89.)

\section{Inleiding}

Wanneer men in Indonesië een bezoek brengt aan de Faculteiten Geneeskunde in Jakarta (Universitas Indonesia) en in Soerabaya (Universitas Airlangga), wordt men onmiddellijk geconfronteerd met het rijke verleden van die faculteiten. In beide steden zijn de faculteiten nog steeds gevestigd in de gebouwen van weleer: in Jakarta in de voormalige Centrale Burger Ziekeninrichting, waarin ook de STOVIA (School Tot Opleiding Van Inlandsche Artsen) was gehuisvest en in Soerabaya in het gebouw van de Nederlandsch Indische Artsen School (NIAS). Zie afbeeldingen 1 en 2.

Hoe kwam het tot oprichting ervan, hoe hebben deze zich in de loop van de tijd ontwikkeld tot de huidige medische faculteiten in Indonesië en wat is de betekenis ervan geweest voor dat land?

\section{Context}

Eeuwenlang heeft de bevolking van het voormalig Nederlands-Indië op het gebied van de geneeskunde hulp gezocht bij lokale genezers, de doekoens. Ook in de huidige tijd, nu er wel artsen beschikbaar zijn, spelen deze doekoens nog steeds een rol. Pas met de komst van de Verenigde OostIndische Compagnie (VOC) deden chirurgijns hun intrede in Nederlands-Indië en in het begin van de negentiende eeuw verschenen enkele academisch opgeleide artsen ten tonele. ${ }^{1}$ Tot ver in de negentiende eeuw waren er grofweg drie soorten artsen in Nederlands-Indië werkzaam: militaire artsen, artsen in dienst van grote ondernemingen (vooral aan de oostkust van Sumatra) en artsen, verbonden aan missie of zending, die uit meer ethische overwegingen hulp aan de bevolking boden. De militaire artsen en de aan de ondernemin- 


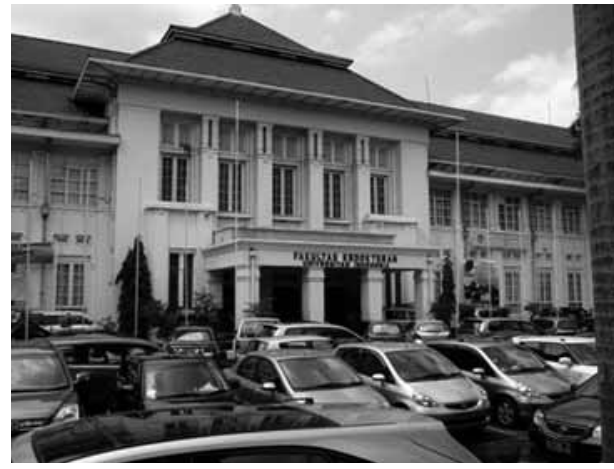

Afbeelding 1. De voormalige Centrale Burger Ziekeninrichting.

gen verbonden artsen voorzagen alleen militairen en burgers van medische zorg; dit was feitelijk een voortzetting van de praktijken van de chirurgijns van de VOC. Tot in de twintigste eeuw was de geneeskunde in Nederlands-Indië gericht op de ondersteuning en versterking van het koloniale systeem en werd dan ook wel 'koloniale geneeskunde' genoemd. ${ }^{2}$

De ontwikkeling van de geneeskunde in Nederlands-Indië is sterk bepaald door militair-politieke en economische omstandigheden. Na het faillissement van de VOC in 1795 werden bezittingen overgenomen door de Nederlandse regering (de Bataafse Republiek) en in 1808 werd door de eerste Gouverneur-Generaal Daendels een Geneeskundige Dienst ingesteld die onder leiding stond van een officier van gezondheid. De werkzaamheden van deze dienst waren in de eerste plaats gericht op militairen, in de tweede plaats op burgers. Daartoe waren onder meer drie ziekenhuizen beschikbaar in Batavia (Weltevreden), Semarang en in Soerabaya.

De officieren van gezondheid waren afkomstig van een niet-universitaire opleiding in Nederland. Naar aanleiding van grote sterfte onder zieke en gewonde militairen aan het eind van de achttiende eeuw was grote behoefte ontstaan aan een gedegen

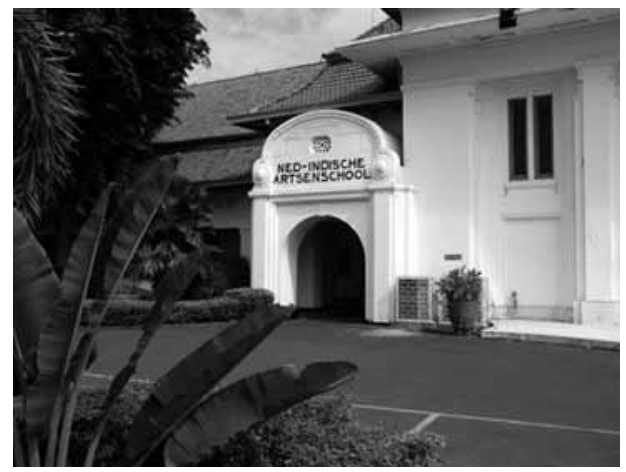

Afbeelding 2. De Nederlandsch Indische Artsen School (NIAS).

opleiding tot officier van gezondheid. Tot dan waren legerchirurgijns (veldscheerders) werkzaam ter ondersteuning van de krijgsmacht. In 1794 werd in Leiden en later in Utrecht de 'Kweekschool voor militair geneeskundigen' ingesteld. In de daarop volgende jaren was het mogelijk, ook voor de in Nederlands-Indië werkzame chirurgijns, via een zij-instroom het diploma officier van gezondheid te verwerven. ${ }^{3}$

\section{Het begin van medische opleidingen in Nederlands-Indië}

Willem Bosch (1798-1874), opgeleid als scheepschirurgijn, was een van de officieren van gezondheid. Als chef van de Geneeskundige Dienst te Batavia ontpopte hij zich als een echte verlichte denker over de geneeskunde in de koloniën. Hij richtte de Vereeniging tot Bevordering der Geneeskundige Wetenschappen en het Geneeskundig Tijdschrift voor Nederlandsch-Indië op; maar zijn grootste verdienste is gelegen in zijn inzet voor de oprichting van de Dokter Djawa school, een tweejarige opleiding tot inheems arts. De aanzet tot die opleiding kwam enerzijds voort uit een toenemende behoefte aan gezonde werkkrachten op de ondernemingen op Java en Sumatra (suiker- en tabaksplantages), en anderzijds uit bezorgdheid over de gevol- 
gen van hevige koortsepidemieën op Midden-Java in 1846-1847, die tienduizenden slachtoffers eisten. Deze toestand werd grotendeels geweten aan armoede en slechte voeding van de inlandse bevolking als gevolg van het Cultuurstelsel, waartegen toenemend maatschappelijke weerstand ontstond. In die context kwam Bosch met voorstellen voor geneeskundige zorg voor de inheemse bevolking, waaronder het verstrekken van voeding en kleding aan zieke inlanders, het inrichten van lokale kleine ziekeninrichtingen en het opleiden van inlanders als hulpgeneesheren. ${ }^{4}$

De Moulin ${ }^{3}$ stelt dat het geen toeval kan zijn dat deze ideeën opkwamen in dezelfde tijd waarin de liberale beweging en het Ethisch Reveil opgang maakten in veel West-Europese landen. Uit de voorstellen van Bosch blijkt tevens dat het gedachtegoed van de hygiënisten ongetwijfeld van invloed is geweest. Het gouvernement ontving de voorstellen met grote verontwaardiging, zij bevatten immers onverholen kritiek op het Cultuurstelsel (zoals de gedwongen verbouw van exportproducten). Na veel strijd ging de Raad van Indië uiteindelijk akkoord met een deel van de voorstellen van Bosch: men besloot dat er een proef zou worden genomen met het opleiden van Javaanse hulpgeneesheren.

Bij Gouvernementsbesluit van 2 januari $1849^{5}$ werd bepaald dat ' 30 jongelieden, die de Maleische en Javaansche taal kunnen lezen en schrijven en een goede aanleg hadden', in de gelegenheid werden gesteld zich kosteloos te bekwamen voor het vak inlands geneeskundige en vaccinateur, om 'na gedurende twee jaren onderwijs te hebben genoten in gouvernementsdienst te worden geplaatst als vaccinateur in districten uit welke zij afkomstig waren, voor het verlenen van geneeskundige hulp'. Naast vrije inwoning ontvingen zij een bezoldiging van $\mathrm{f} 15$,- per maand.
De leiding en regeling van dit onderwijs werd opgedragen aan de chef van de Geneeskundige Dienst; het onderwijs werd verzorgd door drie officieren van gezondheid. In januari 1851 werd onder leiding van de officier van gezondheid $1^{\mathrm{e}}$ klasse P. Bleeker (directeur 1851-1860) een aanvang gemaakt met het geneeskundig onderwijs in Nederlands-Indië: 12 leerlingen begonnen de opleiding in lokalen van het militair hospitaal in Weltevreden. Het onderwijs werd aanvankelijk in het Nederlands gegeven en het programma zag er ambitieus uit. Naast anatomie en fysiologie, plantkunde, dierkunde, pathologie, verloskunde en chirurgie werd ook nog les gegeven in Nederlands, rekenen, meetkunde, aardrijkskunde, sterrenkunde, scheikunde, natuurkunde, werktuigkunde en geologie. De opleiding was gericht op 'het leeren van de techniek der vaccinatie en op het aanbrengen van zoodanige kennis dat in veelvuldig voorkomende ziektegevallen doeltreffende hulp kon worden verleend'. ${ }^{4}$

Hoewel de eerste berichten over de opleiding juichend waren ('het onderwijs in de geneeskunde, heelkunde en de vaccine werd met de meest glansrijke uitkomsten bekroond'), werd snel duidelijk dat de vooropleiding ontoereikend was. Zowel de kennis van de Nederlandse taal als het niveau van rekenen van de aankomende leerlingen bleek van een te beperkt niveau te zijn om de vele theoretische vakken op een bevredigende wijze te kunnen volgen. Dat de lessen uiteindelijk noodgedwongen in het Maleis werden gegeven mocht niet baten, veel leerlingen (van buiten Java) beheersten ook deze taal niet. ${ }^{6}$

Uiteindelijk bleek dat de dokters-djawa ook in de praktijk niet echt bleken te voldoen aan de daar aan hen gestelde eisen. Zij bleken door de gebrekkige opleiding geen zelfstandig beroep als dokter-djawa in de dessa te kunnen uitoefenen. De voornamelijk arme dessabewoners waren overigens ook nau- 
welijks in staat om de dokter-djawa voor zijn diensten enig inkomen te verschaffen. Een en ander leidde tot regeringsmaatregelen in 1864 en in 1875, waarbij de cursusduur werd uitgebreid tot drie, respectievelijk zeven jaar. Vanaf 1875 was twee jaar voorbereidende studie, met aandacht voor lezen, schrijven en rekenen, nodig om een vijfjarige opleiding te kunnen volgen. Het kan geen toeval zijn dat deze veranderingen nauw samenvallen met de Artsenwetten van 1865 en de Hoger Onderwijswet van 1876.

Inmiddels werd het onderwijs in het Nederlands gegeven en vooralsnog alleen in Weltevreden. De plannen voor scholen in Semarang en Soerabaya werden op de lange baan geschoven.

De verslaglegging over de opleiding in de tweede helft van de negentiende eeuw getuigt van veel klaagzangen over de gebrekkige vooropleiding van de leerlingen, de beperkte beschikbaarheid van leerkrachten (onderwijs werd door de officieren van gezondheid als bijzaak beschouwd) en de onvoldoende beschikbaarheid van lesmaterialen voor het theoretische en praktische onderwijs. ${ }^{4}$

\section{Modernisering - STOVIA}

Onder leiding van H.F. Roll (directeur 1896-1899 en 1901-1908) werden, mede gelet op de nieuwe inzichten in de pathofysiologie (Koch, Pasteur, Virchow), vanaf 1898 grote verbeteringen in de opleiding aangebracht. Niet alleen werd, met financiële steun van de Deli Maatschappij, een nieuw gebouw naast het Militaire Hospitaal in Weltevreden betrokken, ook werd het programma aangepast en verlengd tot zes jaar (voorafgaand door een vooropleiding van drie jaar) en werden de poliklinieken (o.a. heelkunde en oogheelkunde) en 'onderwijsbedden' in het militair hospitaal aan de opleiding verbonden.

Met deze veranderingen werden geen dokters-djawa maar veel beter opgeleide artsen afgeleverd, reden waarom in 1899 de naam van de school veranderde in School Tot Opleiding van Inlandsche Artsen (STOVIA). Hiermee werd de fase waarin de westerse geneeskunde in de medische zorg in Nederlands-Indië werd geïntroduceerd afgesloten. Een nieuwe fase werd ingeluid waarin de opleiding geleidelijk toegroeide naar het niveau van een hogeschool en waarin het veel meer tot uitwisseling van ervaringen uit de tropen enerzijds en Europese kennis anderzijds kon komen. ${ }^{2}$

Tevens werd de opleiding geleidelijk losgemaakt van de militair geneeskundige dienst. Zij kwam onder auspiciën van de dienst Onderwijs en de Burgerlijke Geneeskundige Dienst. Er werden burgerleraren benoemd en de school werd verplaatst naar de nabijheid van een ziekenhuisje (Stadsverband) te Glodok, de voorloper van de Centrale Burger Ziekeninrichting die in Salemba gebouwd zou worden, het gebouw waarin ook nu nog de medische faculteit van de Universitas Indonesia is gevestigd.

In diezelfde tijd nam in Europa de belangstelling voor tropische geneeskunde sterk toe, mede door de ontdekking van de verwekkers van cholera, tyfus en malaria en tevens door het onderzoek naar de oorzaken van beri-beri. Dat onderzoek werd in het laboratorium voor Pathologische Anatomie en Bacteriologie in Weltevreden door Eijkman en van Eecke uitgevoerd. Eijkman was van 1888 tot 1896 directeur van de STOVIA en droeg ook met leerboeken fysiologie en scheikunde bij aan de opleiding. Aan Eijkman zou in 1929 voor zijn beri-beri onderzoek de Nobelprijs voor Geneeskunde worden uitgereikt.

\section{Curriculumontwikkeling en internationale oriëntatie}

De opleidingsveranderingen die door Roll in 1899 waren ingevoerd, kregen in 1913 een 
vervolg op zowel organisatorisch als didactisch gebied. In navolging van de situatie in Nederland werd de opleiding geneeskunde uitgebreid van zes naar zeven jaar en deze was toegankelijk voor leerlingen van 'alle rassen, zowel mannelijke als vrouwelijke'. ${ }^{2}$ Leerlingen met HBS (hogereburgerschool) of AMS (algemene middelbare school) werden toegelaten tot de opleiding geneeskunde, die met MULO (meer uitgebreid lager onderwijs) werden geplaatst in het derde jaar van de vooropleiding. Met de toelating van leerlingen van andere komaf dan inlanders, veranderde ook de titel van de afgestudeerde: Indisch arts in plaats van Inlandsch arts.

Een tweede verandering betrof het curriculum en de onderwijsmethodiek. Tot in het begin van de twintigste eeuw bestond, evenals in Europa, een strikte scheiding tussen preklinische (meer theoretische) en klinische, op de praktijk gerichte vakken, waarbij het vooral ontbrak aan enige voorbereiding op het opdoen van klinische ervaring. Rond 1913 kwam daarin verandering. Zoals de toenmalige directeur Noordhoek Hegt (directeur 1908-1914) het verwoordde: 'het leerplan der geneeskundige afdeling der STOVIA is gebaseerd op ondervinding en zoveel mogelijk is daarbij in de volgorde der vakken gestreefd naar overeenkomst met de Hollandse universiteiten.' Over de onderwijsmethodiek schreef hij: 'de onderwijsmethode werd dus als op alle moderne medische scholen: zelf doen, zelf experimenteren, conclusies trekken uit het waargenomene, werktuiglijk uit het hoofd leren tegengaan en zelfwerkzaamheid bevorderen'. ${ }^{2}$ Dit betekende dat naast frontaal onderwijs meer nog het accent gelegd werd op demonstraties, responsiecolleges en practica. Gelijktijdig werden de officieren van gezondheid vervangen door burgerdocenten. ${ }^{7}$

Men was met recht trots op dit curriculum en dat liet men ook in Nederland en daar- buiten weten. Op de wereldtentoonstelling in 1910 in Brussel verzorgde de STOVIA een inzending (een voorloper van een poster) van foto's van de gebouwen, met een overzicht van het curriculum en de ontwikkeling ervan. Een medaille en een erediploma waren het resultaat. Ook op wetenschappelijk gebied liet Nederlands-Indië van zich horen: het Far Eastern Medical Congress werd in 1920 in Batavia georganiseerd.

Evenals dat in de huidige tijd het geval lijkt te zijn, was ook in Nederlands-Indië een curriculum een levensduur van ongeveer tien jaren beschoren: rond 1923 werd een grondige curriculumwijziging met een semestersysteem voorgesteld en ingevoerd. Teneinde een nog betere voorbereiding op de kliniek te bevorderen werden $\mathrm{al}$ in het derde studiejaar klinische vakken gedoceerd en werd het examenreglement zodanig gewijzigd dat een minder groot aantal herkansingen mogelijk was. Tenslotte werd in het vervolg het semi-artsexamen in plaats van een half jaar, een jaar vooraf aan het artsexamen afgelegd. Deze laatste maatregel nam veel van de door de studenten gepercipieerde studiedruk weg. ${ }^{4}$ Evenals eerdere structurele wijzigingen in het curriculum (1864 en 1875) is ook deze verandering ongetwijfeld beïnvloed door het in 1921 in Nederland van kracht geworden nieuwe Academisch Statuut.

De STOVIA maakte een groei- en bloeitijd door: in 1917 waren 187 leerlingen ingeschreven, in 1925 waren dat er al 331. In de volgende jaren werd een nieuwe (derde) fase in de ontwikkeling van het medisch onderwijs ingeluid: de verdere professionalisering en vooral het op universitair niveau brengen van de opleiding. Nadat rond 1920 in Batavia een Rechtshogeschool en in Bandoeng een Technische Hogeschool waren opgericht, werd de opleiding tot arts in Batavia in 1927 onder- 
gebracht bij de Geneeskundige Hoogeschool. Alleen de vooropleiding vond nog binnen de STOVIA plaats. Daarmee werd een periode van vijfenzeventig jaar medisch onderwijs in Weltevreden afgesloten. Zes jaren later hield de STOVIA op te bestaan.

\section{Soerabaya - NIAS}

Uiteindelijk werd het oorspronkelijke plan gerealiseerd om ook buiten Batavia medische opleidingen aan te bieden. Bij besluit van de Gouverneur-Generaal ${ }^{8}$ werd in 1913 in Soerabaya een voorbereidende afdeling geopend van de Nederlandsch Indische Artsen School (NIAS). De school kende een bescheiden start met 30 leerlingen. Het aantal beschikbare leerkrachten was zeer beperkt, in het eerste jaar van het bestaan gaf de directeur bijna alle vakken zelf. Toen men in 1923 een nieuw gebouw had betrokken, het gebouw waarin nu nog steeds de Faculteit der Geneeskunde is gevestigd en waarop nog steeds met trots de naam 'Nederlandsch Indische Artsen School' prijkt, was naast de vooropleiding ook de artsenopleiding in volle gang. Het lerarencorps was inmiddels goed op sterkte, het aantal leerlingen was fors toegenomen en de bibliotheek telde 2000 werken. De selectie vooraf was streng: in 1932 werden van de 211 aangemelde kandidaten er 64 toegelaten. Van de 676 leerlingen die de school toen telde werden 200 uit de opleiding ontslagen, merendeels wegens onvoldoende vorderingen. Uit de verslagen van afgestudeerden in de in die tijd verschenen almanakken kan men opmaken dat de alumni goed in staat bleken te zijn om een zelfstandige praktijk uit te oefenen of zich naderhand te specialiseren. Tot aan de bezetting door de Japanners bleef in Soerabaya de mogelijkheid bestaan van vooropleiding alvorens toegelaten te worden tot de NIAS. ${ }^{9-10}$

\section{Studentenleven en politieke bewust- wording}

Wanneer men de jaarboeken van de faculteiten en de almanakken van de NIAS-vereniging en die der Stovianen leest wordt duidelijk dat zich in Soerabaya en Batavia, met name na 1890 een bruisend studentenleven heeft afgespeeld. Dispuutgezelschappen, sportverenigingen, leesclubs en vele andere genootschappen en clubs bloeiden.

In het medisch dispuutgezelschap van de STOVIA was de discussie over onafhankelijkheid op gang gekomen. Die discussie en de aanzet tot politieke bewustwording was aan het eind van de negentiende eeuw al door directeur Roll gestimuleerd in de context van het Ethisch Reveil, een ontwikkeling die in Nederland opkwam met betrekking tot de koloniale politiek. Zowel de nieuwe ideeën over de praktische kanten van het christelijk geloof als de opkomst van het liberalisme lagen aan deze ontwikkelingen ten grondslag. Het Reveil hield ondermeer in dat de idee van de kolonie als wingewest werd verlaten voor een politiek van investeren in de infrastructuur (wegen en irrigatie) en onderwijs. Ook het verstrekken van kleine leningen en een verbetering van de medische zorg hoorden daarbij, zulks ter verheffing van de inlandse bevolking. Ook werden plannen ontvouwd voor een vorm van volksvertegenwoordiging.

In 1908 leidde dit tot de oprichting van Budi Utomo ('mooie inspanning'), de eerste Indonesische politieke partij, die later onderdeel zou worden van de nationalistische beweging in Nederlands-Indië. Budi Utomo werd opgericht door de gepensioneerde arts Wahidin en enkele medische studenten. Daarmee bood de STOVIA (later de faculteit Geneeskunde) naast de opleiding tot arts, ook een omgeving waarin de studenten in aanraking kwamen met verlichtingsideeën als rationaliteit, democratie en zelfbeschikking. Een en ander leidde tot een politieke bewustwording zonder weerga, die op haar 
beurt een grote deelname van medische studenten en artsen aan de onafhankelijkheidsbeweging tot gevolg heeft gehad. ${ }^{11-12}$

\section{Hoogeschool, oorlogsjaren en universiteit}

Aan de situatie waarin in Jakarta de opleiding geneeskunde binnen de Geneeskundige Hoogeschool werd verzorgd en in Soerabaya binnen de NIAS, kwam een einde in 1942 toen de Japanse bezetter zowel de Hoogeschool als de NIAS sloot. De Japanse regering besloot de opleiding geneeskunde voort te zetten in Klaten (Zuid-Java) onder de naam Ika Daigaku, waar studenten van beide opleidingen welkom waren en waar het onderwijs in het Indonesisch werd verzorgd. In de tijd na de Japanse overgave, waarin de onafhankelijkheid van de Republiek Indonesia werd uitgeroepen, werden de activiteiten van de Ika Daigaku voortgezet onder eigen Indonesisch beheer en als voorbereiding op weerstand van het Nederlandse gouvernement, verspreid over verschillende plaatsen op Java. In 1946 opende de Nederlandse regering de 'Nooduniversiteit van Indonesië' in Jakarta waar aan de faculteit Geneeskunde 63 Chinese, 63 Nederlandse en twee Indonesische studenten werden ingeschreven. In 1947 werd daar door de Indonesiërs de Universitas Indonesia (UI) opgericht, overigens daarin ondersteund door Nederland. Pas in 1948 werd in Soerabaya een dependance van de UI geopend: de faculteit geneeskunde. In 1949 volgde Yogjakarta, waar de Gadjah Mada universiteit werd opgericht, ook met een medische faculteit. In 1954 werd in Soerabaya de Airlangga Universiteit gesticht waarvan toen ook de faculteit geneeskunde onderdeel uitmaakte.

Het is opmerkelijk dat tijdens de politionele acties en ook na de soevereiniteitsoverdracht op 29 december 1948 het onderwijs (dat in het Indonesisch en het Engels werd gegeven) steeds grotendeels werd verzorgd door Nederlandse docenten. Daarin kwam pas verandering tijdens de Nieuw-Guinea crisis in 1958, toen veel Nederlandse docenten Indonesië verlieten. Hun plaats werd aanvankelijk ingenomen door pas afgestudeerde artsen en door studenten die aangesteld werden als assistent-docenten. Overigens waren vele artsen, vanwege hun politieke activiteiten in de Budi Utomo en vanwege hun rol in de guerillaoorlog, in leidinggevende posities in het leger terecht gekomen. Om voor dit kwantitatieve als kwalitatieve tekort aan docenten een oplossing te bieden, sloten zowel de Universitas Indonesia als de Airlangga universiteit een overeenkomst met de University of California Medical School (UCMS) in San Francisco om tot uitwisseling van docenten te komen. De UCMS leverde 29 docenten, terwijl 89 Indonesische docenten naar Berkeley vertrokken voor bij- en nascholing. Deze samenwerking die zes jaar zou duren, heeft een grote impact gehad en dat betrof niet alleen de invoering van de meerkeuzevraag bij de toetsing en een strenger toelatingssysteem. Vanuit de drie faculteiten werd ondersteuning geleverd aan nieuwe opleidingen zodat na afloop van het samenwerkingsverband met de UCMS in 1963 op Java nog twee faculteiten, op Sumatra drie, op Sulawesi (Celebes) twee en op Bali een waren opgericht en uitgerust. ${ }^{13-14}$ Een schematisch overzicht van de ontwikkelingen is weergegeven in Tabel 1.

\section{Tenslotte}

Met het beëindigen van de intensieve samenwerking met de Amerikaanse universiteit trad de vierde fase van ontwikkeling in: de opbouw van meer faculteiten om in de groeiende vraag naar artsen te voorzien. Inmiddels telt Indonesië 55 medische faculteiten (en naar verluid binnenkort 72), verspreid over de gehele archipel. 
Tabel 1. Schematisch overzicht van de ontwikkeling van het medisch onderwijs in voormalig Nederlands-Indië.

\begin{tabular}{llll}
\hline Jaar & Opleiding & Duur & Plaats \\
\hline 1851 & dokter djawa & 2 jaar & Dokter Djawa school, Batavia \\
1864 & dokter djawa & 3 jaar & Dokter Djawa school, Batavia \\
1875 & dokter djawa & 5 jaar +2 jaar vooropleiding & Dokter Djawa school, Batavia \\
1881 & dokter djawa & 5 jaar + 3 jaar vooropleiding & Dokter Djawa school, Batavia \\
1899 & inlandsch arts & 6 jaar + 3 jaar vooropleiding & STOVIA, Batavia \\
1913 & indisch arts & 7 jaar + 3 jaar vooropleiding & STOVIA, Batavia \\
1913 & indisch arts & 7 jaar + 3 jaar vooropleiding & NIAS, Soerabaya \\
1927 & arts & 7 jaar & Geneeskundige Hoogeschool, Batavia \\
1946 & arts & 7 jaar & Nooduniversiteit, Jakarta \\
1947 & arts & 7 jaar & Universitas Indonesia, Jakarta \\
1948 & arts & 7 jaar & Soerabaya: dependance Universitas Indonesia, Jakarta \\
1949 & arts & 7 jaar & Universitas Gadjah Mada, Yogjakarta \\
1954 & arts & 7 jaar & Airlangga Universiteit, Soerabaya \\
\hline
\end{tabular}

De aanblik nu van de gebouwen van STOVIA en NIAS doet denken aan gestolde geschiedenis. Achter die historische façaden zijn echter moderne competentiegerichte curricula met nationaal aanvaarde eindtermen verborgen. Waar Nederland vroeger het curriculum en de organisatie ervan bepaalde, wordt dat nu door de Indonesiërs zelf gedaan. De decanen en stafleden geven aan grote behoefte te hebben aan samenwerking met Nederlandse universiteiten op gebieden als research en curriculumontwikkeling. Momenteel lopen er verscheidene projecten, gericht op research, kwaliteitszorg (o.a. vrijwillige visitatie) en vernieuwing van curricula, waaraan Nederlandse faculteiten deelnemen. Er worden cursussen voor specialisten georganiseerd, onder anderen de Indonesian-Dutch post graduate medical courses die sinds 1980 jaarlijks door Indonesische en Nederlandse docenten worden verzorgd.

\section{Literatuur}

1. Schoute D. De geneeskunde in Nederlandsch-Indië gedurende de negentiende eeuw. Batavia: G.Kolff \& Co; 1936. [Medicine in the Dutch East Indies during the nineteenth century. Batavia: G. Kolff \& Co; 1936].

2. Bergen L van. Van koloniale geneeskunde tot internationale gezondheidszorg. Amsterdam: KIT publishers; 2007. [From colonial medicine to international health care. Amsterdam: KIT publishers; 2007].

3. De Moulin D. Teaching Medicine in the Dutch East Indies. Clio Med 1978-1988; 21:119-124.

4. Waart A de. Ontwikkeling van het geneeskundig onderwijs te Weltevreden, 1851-1926. Weltevreden: G.Kolff \& Co; 1926. [The development of medical education at Weltevreden, 1851-1926. Weltevreden: G. Kolff \& Co; 1926].

5. Gouvernementsbesluit No. 22, Batavia, 2 januari 1849. [Government Order nr. 22, Batavia, 2 January 1849].

6. Lauw G. 'Dokter Djawa' school te Batavia (1850 1875). Spieghel Historiael 1988; 23:75-79. [ Doctor Djawa School at Batavia (1850-1875). Spieghel Historial 1988;23:75-79].

7. De Langen $\mathrm{CD}$. Het geneeskundig onderwijs in Indonesië. Ned.Tijdschr voor Geneesk. 1948;92: 1582-88. [Medical Education in Indonesia. Dutch Journal of Medicine 1948;92:1582-88].

8. Besluit van de Gouverneur-Generaal van Nederlandsch-Indië van 8 mei 1913 No.42: Inlandsche Artsen. Soerabaja. Staatsblad van NederlandschIndië. No.365, Batavia. [Order of the Governor feneral of the Dutch East Indies, 8 May 1913, nr. 42: Native Doctors. Soerabaya. Law Gazette of the Dutch East Indies, Nr. 365, Batavia]. 
9. Jaarboek 1932 uitgegeven door de NIAS- vereeniging. Soerabaya: G.Kolff \& Co; 1932. [Yearbook 1937 published by the NIAS Association. Soerabaya: G. Kolff \& Co: 1932].

10. NIAS almanak, lustrumnummer 1933-1934. Soerabaya: NIAS;1932. [NIAS almanac, special issue celebrating the fifth anniversary. Soerabaya: NIAS 1932].

11. Pols H. Medical Education in the Dutch East Indies and its relation to the emerging National Spirit. Paper presented. Fakultas Kedoktoran, University of Indonesia, Jakarta, May 22, 2007.

12. Pols H. Medical students and Indonesian Independence. Health and History 2008;10:1-5.

13. Gids voor het academiejaar 1949-1950. Universitas Indonesia. Batavia: Landsdrukkerij; 1949. [Guide for the academic year 1949-1950. Universitas Indonesia. Batavia: Landsdrukkerij: 1949].

14. Scott Smyth F. Health and Medicine in Indonesia. J Med Education 1963; 38:693-696.
De auteur:

Prof. dr. R.P. Zwierstra is emeritus hoogleraar medisch onderwijs en opleidingen, Onderwijsinstituut, Universitair Medisch Centrum Groningen.

\section{Correspondentieadres:}

Prof. dr. R.P. Zwierstra, Onderwijsinstituut UMCG, FC 40, A.Deusinglaan 1, Postbus 196, 9700 AD Groningen. Tel.:050-3633057; e-mail r.p.zwierstra@med.umcg.nl

Belangenconflict: geen gemeld

Financiële ondersteuning: geen gemeld

\section{Summary}

The second half of the nineteenth century saw the start of medical education in the former Dutch East Indies. In the early days a two year course trained natives to work as 'vaccinators', and later on an extended curriculum yielded the title of 'native doctor'.

In 1899 the 'School Tot Opleiding van Inlandsche Artsen, STOVIA (School for the Education of Native Doctors) was established at Batavia, followed much later by the 'Nederlandsch Indische Artsen School, NIAS (Netherlands Indies Doctors School) at Surabaya.

Profound changes in the prevailing views on colonialism and the system of forced farming were of overriding importance in the process of change towards the promotion of public health in the Dutch East Indies. At the beginning of the twentieth century the curriculum underwent fundamental changes and was raised to university level. The fact that the academic environment fostered ideas about independence and home rule explains why so many doctors and medical students joined the independence movement.

After World War II there has been a gradual increase in the number of medical schools. Over the decades, except for a brief interruption at the time of the New Guinea crisis, there has been intensive cooperation between Indonesian and Dutch faculties of medicine. (Zwierstra RP. From vaccinators to university-educated doctors. About the history of medical education in the former Dutch East Indies. Dutch Journal of Medical Education 2009;28(2):81-89.) 